\title{
ARTICLE
}

\section{Dispersion of Cs-134 and Cs-137 in river waters from Fukushima and Gunma prefectures at nine months after the Fukushima Daiichi NPP accident}

\author{
Seiya Nagao $^{\mathrm{a}^{*}}$, Masaki Kanamori ${ }^{\mathrm{b}}$, Shinya Ochiai ${ }^{\mathrm{a}}$, Kyuma Suzuki ${ }^{\mathrm{c}}$ and Masayoshi Yamamoto ${ }^{\mathrm{a}}$ \\ ${ }^{a}$ Low Level Radioactivity Laboratory, Kanazawa University, 24 O, Wake, Nomi-shi, Ishikawa-ken, 923-1224, Japan; ${ }^{b}$ Graduate \\ School of Nature and Environmental Technology, Kanazawa University, Kakuma, Kanazawa-shi, Ishikawa-ken, 920-1192, Japan; \\ ${ }^{c}$ Gunma Prefectural Fisheries Experimental Station, 13 Shikishima, Maebashi-shi, Gunma-ken, 371-1036, Japan
}

\begin{abstract}
To estimate short-term and long-term impacts of radiation dose, dynamics of ${ }^{134} \mathrm{Cs}$ and ${ }^{137} \mathrm{Cs}$ in river watershed environments were studied in Fukushima and Gunma prefectures at nine months after the Fukushima Daiichi Nuclear Power Plant (NPP) accident. Radioactivity of ${ }^{134} \mathrm{Cs}$ and ${ }^{137} \mathrm{Cs}$ in the river waters ranged respectively from $0.007 \mathrm{~Bq} / \mathrm{l}$ to $0.149 \mathrm{~Bq} / \mathrm{l}$ and $0.008 \mathrm{~Bq} / \mathrm{l}$ to $0.189 \mathrm{~Bq} / \mathrm{l}$. Their horizontal distributions were consistent with those of material that had been deposited on the ground surface. The percentages of particulate forms of ${ }^{134} \mathrm{Cs}$ and ${ }^{137} \mathrm{Cs}$ were $56-89 \%$ for the Fukushima river samples. Results show that the transport of ${ }^{134} \mathrm{Cs}$ and ${ }^{137} \mathrm{Cs}$ from the watershed to the river waters occurred mainly as particulate forms and that their radioactivity depends on the levels of radioactivity at the watersheds of the respective river systems.
\end{abstract}

Keywords: ${ }^{134} \mathrm{Cs} ;{ }^{137} \mathrm{Cs}$; radiocesium; existence forms; lake waters; transport behavior

\section{Introduction}

A nuclear accident at the Fukushima Daiichi Nuclear Power Plant (NPP) occurred after the 2011 Tohoku Earthquake and Tsunami. About $15 \mathrm{PBq}$ from both ${ }^{134} \mathrm{Cs}$ and ${ }^{137} \mathrm{Cs}$ were released from the Fukushima Daiichi NPP because of venting operations and hydrogen explosions [1-2]. The Ministry of Education, Culture, Sports, Science and Technology of Japan (MEXT) reported total surface deposition of ${ }^{134} \mathrm{Cs}$ and ${ }^{137} \mathrm{Cs}$ in the $80 \mathrm{~km}$ zone from the Fukushima Daiichi NPP [3]. Surface deposition results reveals significant external radioactivity in a zone extending northwest from the NPP: about $20 \mathrm{~km}$ wide and 50-70 km long. However, a mountainous area in Gunma Prefecture, located about $220 \mathrm{~km}$ distance from Fukushima Daiichi NPP south of Fukushima Prefecture, shows similar accumulation of ${ }^{134} \mathrm{Cs}$ and ${ }^{137} \mathrm{Cs}$ [3].

To estimate short-term and long-term impacts of the radiation dose in Japan, it is important to understand the dynamics of radionuclides, especially those of ${ }^{134} \mathrm{Cs}$ and ${ }^{137} \mathrm{Cs}$, on river watershed environments. The study was undertaken to investigate ${ }^{134} \mathrm{Cs}$ and ${ }^{137} \mathrm{Cs}$ radioactivity in river systems in Fukushima and Gunma prefectures, Japan. The secondary radioactive dispersion of ${ }^{134} \mathrm{Cs}$ and ${ }^{137} \mathrm{Cs}$ from the contaminated watershed to the river waters is reported for both research areas with widely various radiocesium deposition on ground surfaces [3] at nine months after the Fukushima Daiichi NPP accident.

*Corresponding author. Email: nagao37@staff.kanazawa-u.ac.jp

\section{Materials and methods}

\subsection{Sampling area}

Five river systems-the Abukuma River, Uta River, Niida River, Natsui River and Same River- were set up as monitoring sites in Fukushima Prefecture, Japan. The Abukuma River has river length of $239 \mathrm{~km}$ and a watershed area of $5400 \mathrm{~km}^{2}$. The other rivers have short river lengths of 43-78 $\mathrm{km}$ and small watersheds of 106-749 $\mathrm{km}^{2}$. The annual mean water discharge of the Abukuma River is $192 \mathrm{~m}^{3} / \mathrm{s}$, as observed in 2008-2009 at Iwanuma Observatory in the lower river area [4]. The other rivers have annual mean discharge of 1.8-14.0 $\mathrm{m}^{3}$ /s for 2000-2005 [5].

In Gunma Prefecture, river research was conducted at the Tone River system, with watershed area of 16840 $\mathrm{km}^{2}$ and river length of $322 \mathrm{~km}$. Its branch rivers, Watarase River and Karasu River, have respective watershed areas of $2621 \mathrm{~km}^{2}$ and $470 \mathrm{~km}^{2}$. The annual mean water discharge of the Tone River was $146 \mathrm{~m}^{3} / \mathrm{s}$ during 1998-2010 at Maebashi Observatory in Gunma Prefecture [4]. The Karasu River was $14.2 \mathrm{~m}^{3} / \mathrm{s}$ at Takasaki for 2002-2010. The Watarase River flow was $20.9 \mathrm{~m}^{3} / \mathrm{s}$ at Takatsudo for 1998-2010 [4].

Lake Akagi-Ohnuma, a holomictic lake [6], is located around the top of Mt. Akagi at about $1350 \mathrm{~m}$ altitude. The lake has a surface area of $0.83 \mathrm{~km}^{2}$ and a watershed area of $4.82 \mathrm{~km}^{2}$. Lake Akagi-Konuma, located near the top of Mt. Choshichiro at altitude of $1470 \mathrm{~m}$, has a lake surface of $0.1 \mathrm{~km}^{2}$. The lake waters overflowing from both lakes run through tributaries to the Tone River. 

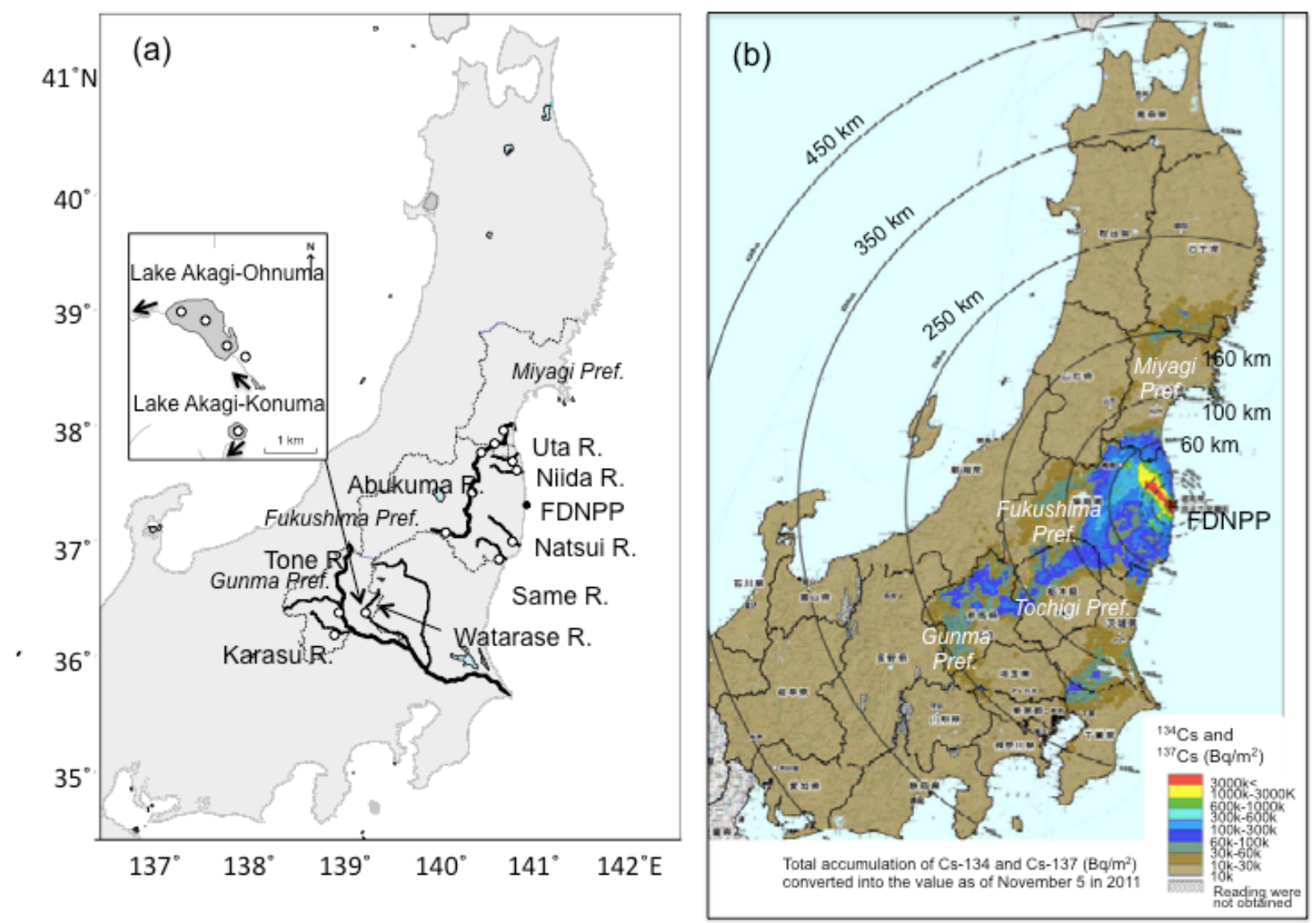

Figure 1. Sampling locations in this study (a) and distribution of ${ }^{134} \mathrm{Cs}+{ }^{137} \mathrm{Cs}$ measured by the fourth airborne monitoring by MEXT (b). Open circles indicate the sampling sites for the measurements of ${ }^{134} \mathrm{Cs}$ and ${ }^{137} \mathrm{Cs}$ radioactivity in the river and lake waters. Solid lines drawn on the map in Figure 1(a) indicate the distribution of each river. Dashed lines indicate prefectural border. FDNPP indicates Fukushima Daiichi Nuclear Power Plant. Figure 1(b) was modified from [3].

\subsection{Sampling}

Figure 1 shows monitoring sites in the river systems in Fukushima Prefecture and Gunma Prefecture and the accumulation of ${ }^{134} \mathrm{Cs}+{ }^{137} \mathrm{Cs}$ on the ground surface. The surface river water in the streamline was collected from a bridge at a monitoring site in the Uta River, Niida River, Natsui River, and Same River on 6-7 December 2011. The Abukuma River has five such monitoring sites from upstream (Shirakawa) through midstream (Motomiya and Date) to downstream (Marumori and Iwanuma). River research was also conducted at monitoring sites in the Tone River, the Karasu River, and the Watarase River in Gunma Prefecture on 15-16 December 2011. Surface water samples from Lake Akagi-Ohnuma and Lake Akagi-Konuma were collected using a bucket on 11 December 2011. Water samples in middle and bottom layers at the center of Lake Akagi-Ohnuma were collected using a Van Dorn water sampler. The water discharge was a normal flow condition in each river during the samplings [4,7].

\subsection{Measurements}

${ }^{134} \mathrm{Cs}$ and ${ }^{137} \mathrm{Cs}$ were concentrated onto ammonium molybdophosphate (AMP) [8] for 10-20 l of raw river waters and filtered river waters using cartridge filters with pore sizes of $10 \mu \mathrm{m}, 1 \mu \mathrm{m}$ and $0.45 \mu \mathrm{m}$ sequentially. The AMP/Cs compound was dried at room temperature and weighed to determine the weight yield of AMP/Cs compound. The averaged yield was $91 \pm 5 \%$ for all water samples. The dried AMP/Cs compound was packed into a polyethylene bag $(3.5 \mathrm{~cm} \times 7.0 \mathrm{~cm})$.

The radioactivity of ${ }^{134} \mathrm{Cs}$ and ${ }^{137} \mathrm{Cs}$ was measured for the AMP/Cs compound using gamma-ray spectrometry with low background Ge detectors (GEM-251855 of ORTEC ${ }^{\circledR}$ and other similar models) equipped with a multichannel analyzer (Model 7700 of SEIKO EG\&G Co. Ltd. and other similar models) at the Low Level Radioactivity Laboratory and the Ogoya Underground Laboratory of Kanazawa University during 1-3 days. Gamma emission peaks were used for calculating activity at $605 \mathrm{keV}$ and $795 \mathrm{keV}$ for ${ }^{134} \mathrm{Cs}$ and $661 \mathrm{keV}$ for ${ }^{137} \mathrm{Cs}$. The cascade summing effect was corrected for ${ }^{134} \mathrm{Cs}$ using a Fukushima contaminated soil sample. Decay correction of radioactivity for ${ }^{134} \mathrm{Cs}$ and ${ }^{137} \mathrm{Cs}$ was done at each sampling date. The ${ }^{134} \mathrm{Cs}$ and ${ }^{137} \mathrm{Cs}$ radioactivity is designated as the total (dissolved + particulate phase) radioactivity for the raw river and lake 
Table 1. Physicochemical parameters and radioactivity of ${ }^{134} \mathrm{Cs}$ and ${ }^{137} \mathrm{Cs}$ in river and lake waters in Fukushima Prefecture and Gunma Prefecture, Japan.

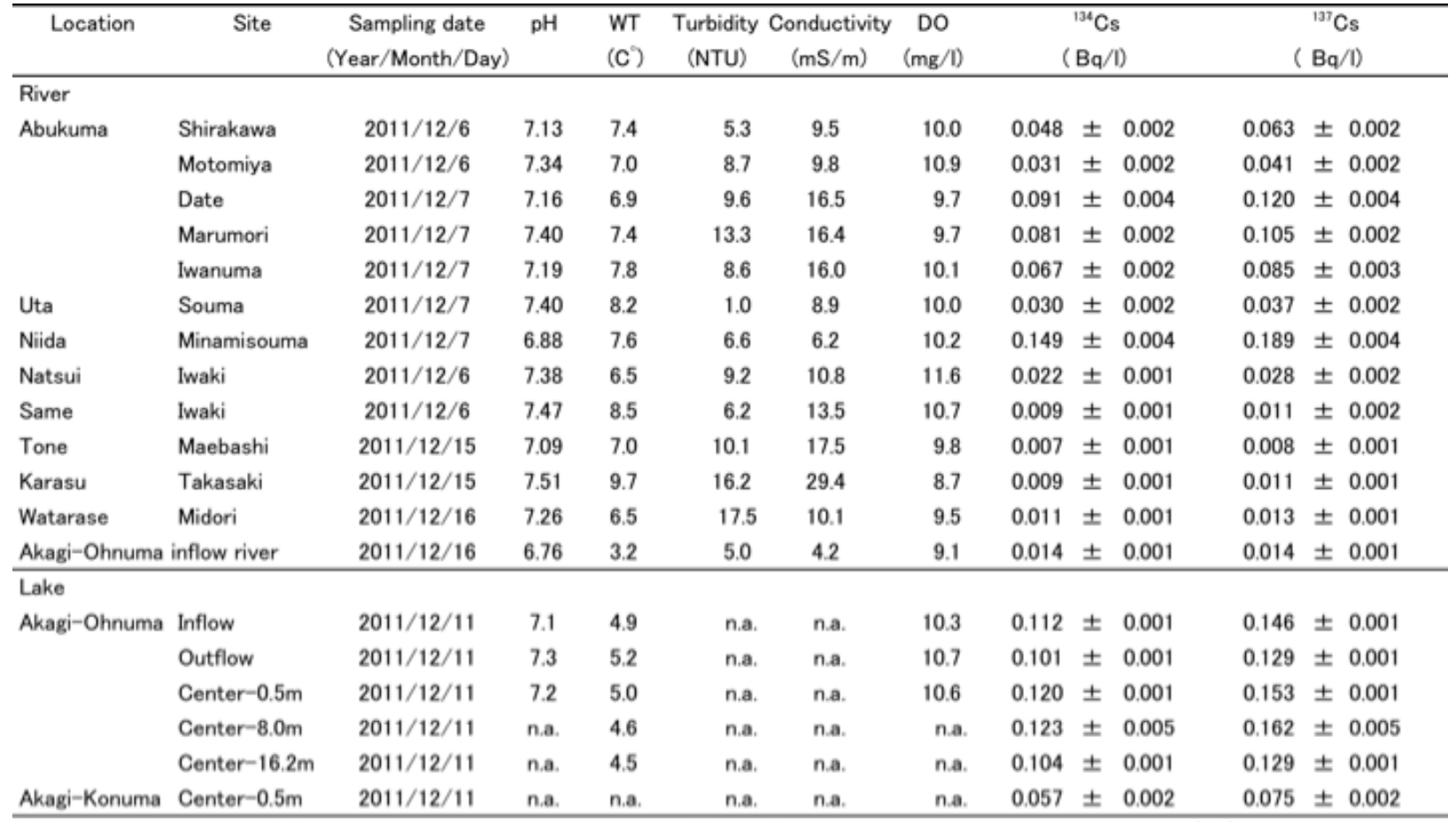

$\mathrm{WT}=$ water temperature. $\mathrm{DO}=$ dissolved oxygen. $\mathrm{n} . \mathbf{a} .=$ not analysis. Errors of radioactivity indicate the counting errors $(1 \mathrm{\sigma})$.

waters, and is as dissolved radioactivity for filtered river waters. The ${ }^{134} \mathrm{Cs}$ and ${ }^{137} \mathrm{Cs}$ particulate phase was estimated by subtracting the radioactivity of dissolved phase from the total value for raw river waters.

\section{Results and discussion}

\subsection{Water chemistry}

The physicochemical parameters of river and lake waters are presented in Table 1. The river water $\mathrm{pH}$ was 6.76-7.51. The conductivity was $4.2-29.4 \mathrm{mS} / \mathrm{m}$. The turbidity was 1.0-17.5 NTU. The dissolved oxygen (DO) concentration was $8.7-11.6 \mathrm{mg} / \mathrm{l}$.

\subsection{Radioactivity of ${ }^{134} \mathrm{Cs}$ and ${ }^{137} \mathrm{Cs}$}

Table 1 shows ${ }^{134} \mathrm{Cs}$ and ${ }^{137} \mathrm{Cs}$ radioactivity in surface river water samples from Fukushima Prefecture on December $6-7,2011$. The ${ }^{137} \mathrm{Cs}$ radioactivity ranges from $0.011 \mathrm{~Bq} / \mathrm{l}$ to $0.189 \mathrm{~Bq} / \mathrm{l}$ and decreases downward from the Shirakawa site to the Motomiya site and then shows maximum value at the Date site in the Abukuma River.

The ${ }^{137} \mathrm{Cs}$ radioactivity ranges from $0.008 \mathrm{~Bq} / \mathrm{l}$ to $0.014 \mathrm{~Bq} / \mathrm{l}$ for river water samples from the Tone River systems and a small river flowing into Lake Akagi-Ohnuma. These values resemble those of the Same River and the Natsui River in the south part of Fukushima. However, surface water samples in Lake Akagi-Ohnuma and Lake Akagi-Konuma show ${ }^{137} \mathrm{Cs}$ radioactivity ranging from $0.075 \mathrm{~Bq} / \mathrm{l}$ to $0.153 \mathrm{~Bq} / \mathrm{l}$.
Their values are 1-2 orders of magnitude higher than those of river waters in Gunma Prefecture. The radioactivity of ${ }^{137} \mathrm{Cs}$ at the center of Lake Akagi-Onuma ranges from $0.129 \mathrm{~Bq} / \mathrm{l}$ to $0.162 \mathrm{~Bq} / \mathrm{l}$, and is almost constant with water depth. The ${ }^{134} \mathrm{Cs} /{ }^{137} \mathrm{Cs}$ activity ratio of all samples was nearly 1.0 within measurement error after the decay correction to March 11 in 2011. Therefore, a major part of radiocesium is derived from the Fukushima Daiichi NPP accident.

The higher radioactivity for the waters of Lake Akagi-Ohnuma and Lake Akagi-Konuma was probably attributed to the stability of cesium in lake water as dissolved forms [9-10] and the longer residence time (2.4 years) of lake waters [6]. The still high radioactivity of ${ }^{137} \mathrm{Cs}$ in waters was observed in closed lakes, with no marked surface inflow and outflow of water, in the Chernobyl exclusion zone [11].

Table 2 presents the range of ${ }^{137} \mathrm{Cs}$ radioactivity for the river waters in these areas (Fukuhsima, Miyagi, Ibaraki and Gunma prefectures, see Figure 1) before and after the Fukushima Daiichi NPP accident. Before the accident, the radioactivity ranges from $0.05-1.89 \times 10^{-3}$ $\mathrm{Bq} / \mathrm{l}$ [12-13] for the Tone River and the Kuji River, which originate from the southern end of mountainous region of Abukuma. The radioactivity increased to $0.01-0.19 \mathrm{~Bq} / \mathrm{l}$ after the accident. These values are $2-3$ orders higher than those before the accident. The differences in radioactivity of ${ }^{137} \mathrm{Cs}$ before and after the accident was probably attributed to the transport of radiocesium from the contaminated watershed. 
Table 2. Radioactivity of ${ }^{137} \mathrm{Cs}$ in river waters before and after the Fukushima Daiichi NPP accident in Fukushima, Ibaraki and Gunma prefectures, Japan.

\begin{tabular}{cccc}
\hline River & Date & $\begin{array}{c}{ }^{137} \mathrm{Cs} \\
(\mathrm{Ba} / \mathrm{l})\end{array}$ & Reference \\
\hline \multicolumn{4}{c}{ After the Fukushima Diichi NPP accident } \\
Abukuma & 2011 & $0.041-0.120$ & This study \\
Niida & 2011 & 0.189 & This study \\
Uta/Same/Natsui & 2011 & $0.011-0.037$ & This study \\
Tone/Karasu/Watarase & 2011 & $0.008-0.013$ & This study \\
\multicolumn{4}{c}{ Before the Fukushima Daichi NPP accident } \\
Tone & $1985-1987$ & $(0.16-1.89) \times 10^{-3}$ & Hirose et al. [12] \\
Kuji & $1987-1989$ & $(0.05-1.00) \times 10^{-3}$ & Matsunaga et al. [13] \\
\hline
\end{tabular}

\subsection{Existing forms of radiocesium}

To ascertain the present circumstances and transport behavior of radiocesium, we analyzed existing forms of radiocesium in river waters using the filtration method described in 2.3 Measurements. The percentage of particulate form of ${ }^{137} \mathrm{Cs}$ was estimated for the Fukushima river water samples. The particulate form of radiocesium was $89 \%$ for the Shirakawa sample upstream, 61-62\% for Motomiya and Date midstream, 56\% for Marumori, and 76\% for Iwanuma downstream of the Abukuma River. The fraction of particulates varied 20 percentage points from upstream to downstream in the Abukuma River. The Uta and Niida rivers were, respectively, $58 \%$ and $80 \%$.

Table 3 shows averaged percentages of particulate ${ }^{137} \mathrm{Cs}$ in river waters before and after the Fukushima Daiichi NPP accident. The percentage of particulate ${ }^{137} \mathrm{Cs}$ for the Fukushima rivers after the Fukushima Daiichi NPP accident became 20-30 percentage points higher than those of rivers before the accident [12-14]. Differences reported at the Pripyat River with 40-60\% [15] and other river systems with 4-80\% [16] after the Chernobyl accident, depending on water chemistry and composition, and on the concentration of suspended solids in river waters.

Table 3. Averaged percentages of ${ }^{137} \mathrm{Cs}$ radioactivity in particles to the total radioactivity for river waters.

\begin{tabular}{ccccc}
\hline River & \multicolumn{2}{c}{ Particulate ${ }^{137} \mathrm{Cs}(\%)$} & No. of & Reference \\
\cline { 2 - 4 } & Rnage & Averaged valu samples & \\
\hline Abukuma & After the Fukushima Daiichi NPP accident \\
Niida & $56-89$ & $71 \pm 12$ & 6 & This study \\
Uta & 80 & 80 & 1 & This study \\
\multicolumn{5}{c}{ Before the Fukushima Daiichi NPP accident } \\
Tone & $11-36$ & $21 \pm 9$ & 5 & Hirose et al. [12] \\
Kuji & $22-80$ & $43 \pm 19$ & 8 & Matsunaga et al. [13] \\
Pripyat/Sakhan & $2-50$ & $16 \pm 20$ & 5 & Matsunaga et al. [14] \\
\hline
\end{tabular}

\subsection{Transport of ${ }^{134} \mathrm{Cs}$ and ${ }^{137} \mathrm{Cs}$ in river systems}

Figure 2 shows the distribution of ${ }^{137} \mathrm{Cs}$ in river waters from Fukushima and Gunma prefectures in December 2011. A highly contaminated area (>60 $\mathrm{kBq} / \mathrm{m}^{2}$ ) is the eastern area of Fukushima Prefecture, extending into the northern parts of Tochigi and Gunma prefectures, as shown in Figure 1(b). The distribution pattern of river water ${ }^{137} \mathrm{Cs}$ is consistent with the distribution of ${ }^{134} \mathrm{Cs}$ and ${ }^{137} \mathrm{Cs}$ accumulated on surface soil in Fukushima and Gunma prefectures [3]. The Niida River shows the highest ${ }^{137} \mathrm{Cs}$ radioactivity among the rivers, but the Niida River is a small watershed area. The lower Niida River and Uta River show less accumulation $\left(<100 \mathrm{kBq} / \mathrm{m}^{2}\right)$ for radiocesium, but the upper Niida River shows accumulation of $1000-3000 \mathrm{kBq} / \mathrm{m}^{2}$ (Figure 1(b)). Ueda et al. [17] reported that the ${ }^{137} \mathrm{Cs}$ radioactivity in river waters from the tributaries of upper Niida River was $0.25-0.49 \mathrm{~Bq} / \mathrm{l}$ on November 21-22, 2011. These values are 1-3 times higher than the downstream Niida River in this study. Particulate forms of ${ }^{137} \mathrm{Cs}$ were $48 \pm 10 \%$ for the upper Niida [17] and $80 \%$ for the lower Niida. These results suggest that radiocesium deposited on the surface is mainly exported as existing forms adsorbed with suspended particles, clay minerals [18], and organic matter [13] in the rivers.

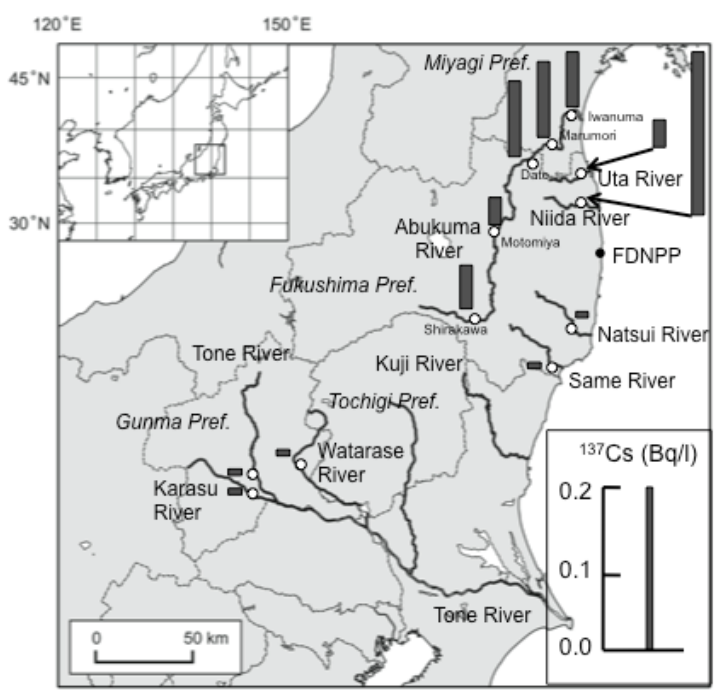

Figure 2. Distribution of ${ }^{137} \mathrm{Cs}$ radioactivity in the river waters from Fukushima and Gunma Prefecture, Japan on December 6-16, 2011. FDNPP = Fukushima Daiichi Nuclear Power Plant. The map data was used from Global Map Japan version 2 of the Geospatial Information Authority of Japan [19].

\section{Conclusion}

To assess secondary radioactive migration of ${ }^{134} \mathrm{Cs}$ and ${ }^{137} \mathrm{Cs}$ in river watersheds, we measured the radioactivity for river waters collected from the six river systems in Fukushima and Gunma Prefecture, Japan at nine months after the Fukushima Daiichi NPP accident. The radioactivity level of ${ }^{137} \mathrm{Cs}$ in the river waters at Fukushima Prefecture was $0.011 \mathrm{~Bq} / \mathrm{l}$ to $0.189 \mathrm{~Bq} / \mathrm{l}$, and $0.008 \mathrm{~Bq} / \mathrm{l}$ to $0.014 \mathrm{~Bq} / \mathrm{l}$ for Gunma rivers. The radioactivity depends on the level of ${ }^{134} \mathrm{Cs}$ and ${ }^{137} \mathrm{Cs}$ contamination in the watershed. Particulate forms of ${ }^{134} \mathrm{Cs}$ and ${ }^{137} \mathrm{Cs}$ at normal flow conditions were $58-89 \%$ of total radioactivity on average of $71 \pm 12 \%$. Therefore, radiocesium deposited on the ground surface in these river watersheds was exported dominantly from watershed to river as particulate forms. 


\section{Acknowledgements}

This study was partly funded by a Grant-in-Aid for Scientific Research No. 24310009 and 24110008 from the Ministry of Education, Culture, Sports, Science and Technology of Japan.

\section{References}

[1] Japanese Government, Report of Japanese Government to the IAEA Ministerial Conference on Nuclear Safety -The Accident at TEPCO's Fukushima Nuclear Power Stations -, (2011), http://www.kantei.go.jp/foreign/kan/topics/201106/ iaea_houkokusho_e.html.

[2] M. Chino, H. Nakayama, H. Nagai, H. Terada, G. Katata and H. Yamazawa, Preliminary estimation of release amounts of ${ }^{131} \mathrm{I}$ and ${ }^{137} \mathrm{Cs}$ accidentally discharged from the Fukushima Daiichi Nuclear Power Plant into the atmosphere, J. Nucl. Sci. Technol. 48 (2011), pp. 1129-1134.

[3] MEXT (2011), http://radioactivity.mext.go.jp/en/ contents/5000/4901/24/1910_1216.pdf. Japanese]

[4] Ministry of Land, Infrastructure and Transport, Japan, Water Information System, http://www1.river.go.jp/ [in Japanese]

[5] Fukushima Prefectural Government, Report on Information of Water Area (River) Planning Environmental Standard Zoning, (2007), p. 211.

[6] T. Kondoh and H. Hamada, Limnological research on Lake Onuma, Bulletin of the Faculty of Education, Chiba University 59 (2011), pp. 319-332.

[7] Fukushima Prefectural Government, System Data for River Information in 2011.

[8] M. Inoue, H. Kofuji, M. Yamamoto and K. Komura, Seasonal variation of ${ }^{228} \mathrm{Ra} /{ }^{226} \mathrm{Ra}$ ratio in seaweed Influence on the environmental changes of the coastal area, Noto Peninsula, Japan-, J. Environ. Radioactivity 80 (2005), pp. 341-355.

[9] A. V. Konoplev, A. A. Bulgakov, V. G. Zhirnov et al., Study of the behavior of Cs-137 and Sr-90 in Svyatoe and Kozhanovskoe lakes in the Bryansk region, Meteorol. Gidrol. 11 (1998), pp. 78-87. [in Russian]

[10] G. Zibold, S. Kaminski, E. Klemt and J. T. Smith, Time-dependency of the ${ }^{137} \mathrm{Cs}$ activity concentration in freshwater lakes, measurement and prediction, Radioprotection - Colloques 37 (2002), pp.75-80.

[11] O. V. Voitsekovich, V. Kanivers and Y. Onishi, The Chernobyl accident and its aquatic impacts on the surrounding area, Chernobyl - What Have We
Learned? The Success and Failures to Mitigate Water Contamination over 20 Years (eds. Y. Onishi, O. V. Voitsekhovich and M. J. Zheleznyak), Spriger, Dordrecht, (2007), pp. 9-47. ISBN 101402053487

[12]K. Hirose, M. Aoyama and Y. Sugimura, Plutonium and cesium isotopes in river waters in Japan, J. Radioanal. Nucl. Chem. Articles 141 (1990), pp. 191-202.

[13] T. Matsunaga, H. Amano and N. Yanase, Discharge of dissolved and particulate ${ }^{137} \mathrm{Cs}$ in the Kuji River Japan, Appl. Geochem. 6 (1991), pp. 159-167.

[14] T. Matsunaga, T. Ueno, H. Amano, Y. Tkachenko, A. Kovalyov, M. Watanabe and Y. Onuma, Characteristics of Chernobyl-derived radionuclides in particulate form in surface waters in the exclusion zone around the Chernobyl Nuclear Power Plant, J. Contaminant Hydrol. 35 (1998), pp. 101-113.

[15] O. V. Voitsekhovitch, O. Nasvit, I. Los and V. Berkovski, Present thoughts on aquatic countermeasures applied to regions of the Dnieper river catchment contaminated by the 1986 Chernobyl accident, Freshwater and Estuarine Radioecology (eds. G. Desmet, R. Blust, R.N.J. Comans, J.A. Fernandez, J. Hilton and A. de Bettencourt), Elsevier, Amsterdam, (1997), pp.75-86.

[16]R. N. J. Comans, T. Bergen, R. Blust, C. Vaz Carreiro, J. Fernandez, L. Hakanson, U. Sakanoue and J. T. Smith, Modelling Fluxes and Bioavailability of Radiocaesium and Radiostrontium in Freshwaters in Support of a Theoretical Basis for Chemical/Hydrological Countermeasures, Final Report to the European Commission, Netherlands Energy Research, Petten, (1999).

[17] S. Ueda, H. Hasegawa, H. Kakiuchi, N. Akata, Y. Ohtsuka and S. Hisamatsu, Fluvial discharges of radiocesium from watersheds contaminated by the Fukushima Dai-ichi Nuclear Power Plant accident, Japan, J. Environ. Radioactivity 118 (2013), pp. 96-104.

[18] E. M. Korobova and N. P. Chizhikova, Distribution and mobility of radiocesium in relation to the clay fraction mineralogy and soil properties in the Iput River flood plain, Eurasian Soil Sci. 40 (2007), pp. 1062-1075.

[19] Geospatial Information Authority of Japan, Global Map Japan version 2, http://www1.gsi.go.jp/geowww/globalmap-gsi/dow nload/index.html. 